\title{
Ewa Kurantowicz (red.), „Poradnik trenera osób starszych. Seria: Silver Team, czyli potęga doświadczenia", Wyd. Dobre Kadry Centrum Badawczo-Szkoleniowe, Wrocław 2013
}

Publikacja pod redakcją Ewy Kurantowicz, Poradnik trenera osób starszych została przygotowana przez zespół andragogów: Adriannę Nizińską (rozdział I i II), Magdalenę Czubak-Koch (rozdział III), Annę Helmich-Zgodę, Agnieszkę Pietrus-Rajman oraz Sylwię Wronę (rozdział IV). Powstała w ramach projektu „Silver Team czyli potęga doświadczenia” współfinansowanego ze środków Unii Europejskiej w ramach Europejskiego Funduszu Społecznego, priorytet VI Rynek pracy otwarty dla wszystkich, działanie 6.4 Projekty innowacyjne. Jego celem jest wydłużenie aktywności zawodowej osób w wieku 50+ dzięki wypracowaniu kompleksowego, innowacyjnego narzędzia zarządzania kapitałem ludzkim i aktywizacji osób starszych. Jak podaje się na stronie projektu - cel ten ma zostać osiągnięty poprzez realizację następujących działań:

- Nadanie właściwego kierunku polityce wspierania osób starszych na rynku pracy poprzez dogłębną analizę rozwiązań w tym zakresie, wykorzystanie metod zarządzania wiedzą, teorii motywowania, dobrych europejskich praktyk.

- Polepszenie sytuacji osób starszych na rynku pracy poprzez wypracowanie kompleksowego pakietu „Doświadczony pracownik”.

- Upowszechnienie i wdrożenie do głównego nurtu polityki efektywnego narzędzia zarządzania kapitałem ludzkimi aktywizacji osób starszych.

Publikacja jest jedną z sześciu zaplanowanych w ramach pakietu „Doświadczony pracownik": 
1. Strategia efektywnego zarządzania zasobami ludzkimi z elementami zarządzania wiedzą (wskazanie roli, miejsca i wartości osoby starszej w firmie czy instytucji).

2. Poradnik „Doświadczony pracownik jako mentor/tutor/coach”.

3. Poradnik trenera osób starszych.

4. Kompendium innowacyjnych metod uczenia się bez bariery wieku.

5. Raport na temat obszarów niszowych rynku w zakresie usług.

6. Program szkoleń przygotowujących do wykonywania trzech przykładowych zawodów zidentyfikowanych jako niszowe i odpowiednie dla osób z grupy $50+$.

Redaktor E. Kurantowicz opatrzyła publikację wstępem, w którym zwróciła uwagę, że posiada cechy, które charakteryzują dobry poradnik czyli „pozwala zdobyć nie tylko rzetelną wiedzę instrumentalną, ale równocześnie jego treści stają się podstawą do dalszych działań samokształceniowych i rozwoju kompetencji czytelników w danej problematyce".

Poradnik trenera osób starszych składa się z czterech rozdziałów. W rozdziale I Najważniejsze wnioski ze współczesnych teorii uczenia się i nauczania, jego autorka: Adrianna Nizińska odwołała się do siedmiu aspektów uczenia się dorosłych według K. Tusting i D. Bartona: motywacji, inicjatywy, specyfiki procesu uczenia się, uczenia się w codzienności, doświadczenia, incydentalnego nieformalnego charakteru uczenia się oraz potencjału transformacyjnego, które skrótowo omówiła. W kolejnych podrozdziałach zostały omówione klasyczne i konstruktywistyczne zasady dydaktyki dorosłych, cztery typy orientacji uczących się przez całe życie wg Vestera i J. Fielda, a także główne bariery w uczeniu się dorosłych oraz zagadnienie warunków uczenia się a podejście do nauczania wg P. Jarvisa.

Rozdział II Uczenie się w dojrzałej i późnej dorosłości - również autorstwa Adrianny Nizińskiej - stanowi analizę w oparciu o teorie Moschisa (gerontograficzny podział na cztery typy starzenia się osób $55+$ ), Tippelta (typologia uczących się starszych) oraz Maya (charakterystyka osoby starszej jako ucznia, $z$ uwzględnieniem zmian fizycznych, w sferze poznawczej oraz potrzeb społeczno-emocjonalnych).

W rozdziale III Magdalena Czubak-Koch przeanalizowała zagadnienie planowania i przebiegu procesów edukacyjnych w dojrzałej i późnej dorosłości. Szerzej zostały omówione przesłanki organizowania edukacji dla dojrzałych dorosłych, zadania nauczyciela osób starszych, etapy planowania procesu dydaktycznego i techniki wspierające oraz fundamentalne zasady przebiegu nauczania dojrzałych dorosłych. 


\section{4 | Poradnik trenera osób starszych}

Rozdział IV opracowany przez Annę Helmich-Zgodę, Agnieszkę Pietrus-Rajman oraz Sylwię Wronę - stanowi podsumowanie po etapie testowania, które polegało na przeprowadzeniu 32 godzin szkoleń dla 13 trenerów osób starszych. Jego uczestnikami byli przedstawiciele publicznych oraz niepublicznych instytucji szkoleniowych, którzy chcieli zapoznać się ze specyfiką nauczania osób dojrzałych.

Poradnik stanowi kompendium wiedzy skierowanej do osób zajmujących się pracą szkoleniową z osobami starszymi. Jego mocną stroną jest staranne wydanie, treści są prezentowane w sposób przejrzysty i skondensowany, często w formie wypunktowań lub zestawień tabelarycznych. Czytelnik znajdzie w niej zarówno zarysy kluczowych koncepcji, jak i praktyczne wskazówki.

Alina Matlakiewicz 